\title{
The effects of corporate governance mechanisms on earnings management: Empirical evidence from Moroccan listed firms
}

Yousra El Mokrani ${ }^{*}$, Youssef Alami ${ }^{2}$

Laboratory of Finance, Audit and Management Research, LAREFAG, ENCG, Abdelmalek Essaadi University, Tetouan, Morocco ${ }^{1,2}$

yousra.mokraniel@gmail.com ${ }^{1 *}$, alamiyou@yahoo.fr ${ }^{2}$

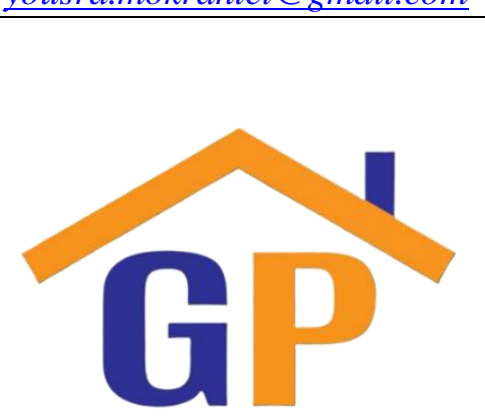

Article History

Received on 23 April 2021

Revised on 19 May 2021

Accepted on 27 May 2021

\begin{abstract}
Purpose: The purpose of the study is to systematically review and examine the effectiveness of corporate governance mechanisms in restraining earnings management among the listed firms of the Casablanca Stock Exchange.

Research methodology: In this study, we used the modified Jones model to calculate discretionary accruals. Our sample comprises 27 firms covering the period from 2016 to 2018 , analyzed by the EGLS estimator.
\end{abstract}

Results: Our empirical results show that gender diversity, board size, and audit committee independence reduce the managers' discretion. Simultaneously, we found a significantly positive association between earning management and different corporate governance characteristics such as CEO duality, institutional investor ownership, and family ownership. We do not find any evidence that audit committee size, ownership concentration, and managerial ownership significantly influence discretionary accruals.

Limitations: This study's main limitation is that we did not address the direction of discretionary accruals, which does not allow us to detect the motivational aspects behind earnings management.

Contribution: The results of this study will help Moroccan authorities in their formulation of an appropriate regulatory framework because very few studies have been conducted in this area in the case of the Moroccan listed companies, especially with a large set of governance variables as our empirical model.

Keywords: Accruals, Board of directors, Corporate governance, Earnings management, Ownership structure.

How to cite: Mokrani, Y, E., \& Alami, Y. (2021). The effects of corporate governance mechanisms on earnings management: empirical evidence from Moroccan listed firms. International Journal of Financial, Accounting, and Management, 3(3), 205-225.

\section{Introduction}

Earnings manipulation is considered one of the most critical issues in financial reporting over the last two decades. Large companies' opportunistic management behavior seems to be a major topic of debate in the economic and financial world after several financial scandals. When companies such as Enron and WorldCom were put in the spotlight in the early 2000s, it was revealed that the management team had taken extreme measures to prepare their financial statements. The former CEO of WorldCom, Scott Sullivan, publicly stated that he "falsified the financial statements to fulfill analysts' expectations" (Bowe, 2005). Faced with intense pressure to achieve the financial numbers predicted by analysts, the management team deliberately used several techniques to manage their earnings. Although they are widely recognized, both Enron and WorldCom have taken earnings management practice to the law's fraudulent extreme. These financial scandals have created an atmosphere of uncertainty and mistrust in the financial markets. To break away from this environment of mistrust, an inevitable corporate 
governance reform has been developed that limits managers' opportunistic behavior and undermines investors' reliability in financial information. Solid governance mechanisms would reduce opportunistic management behavior, thus enhancing financial statements and earnings management reliability and quality. On the other hand, an inefficient governance system can encourage manipulation, mismanagement, and corruption in the firm (Karamanou and Vafeas, 2005).

Morocco is a developing country that needs to attract new suppliers, investors, and lenders. The disclosure of the Moroccan companies' results is associated with requirements in terms of corporate governance mechanisms and managing earnings".

This paper is one of the first attempts to provide evidence on the impact of governance mechanisms on earnings management in Moroccan listed companies. Most recent studies have focused on the relationship between performance and corporate governance (Sbai and Meghouar, 2017; Belkebir et al. 2018). While discovering the interplay between corporate governance and earnings management is still limited in the Moroccan context, because earlier studies have focused especially on the impact of ownership structure on earnings management (El Haddad and Ez-Zarzari, 2017; Farooq and El Jai, 2012). To address these limitations, we examine the relationship between earnings management and corporate governance mechanisms, including both board of directors and ownership structure characteristics, following the approach of Kjærland et al. (2020). The study's primary focus is to understand that a well-functioning governance system effectively controls the earnings management in Moroccan listed companies.

This study's main purposes are to explain the nature of the relationship between earnings management and corporate governance mechanisms in the Casablanca Stock Exchange (CSE). To identify the characteristics of corporate governance that have major effects on earnings management and to assess the econometric power and relevance of the accrual-based model of Dechow et al. (1995) for detecting earnings management in the Moroccan stock market context.

This contribution is structured as follows. After the introduction, in section 1, we examine definitions of the concept of earnings management. Section 2 presents the literature on earning management and corporate governance characteristics and develops research hypotheses. In section 3, we expose our research methodology, sample, and empirical methods, including how we estimate discretionary accruals and explanatory variables. Whereas in Section 5, we expose and interpret the main achieved empirical results before concluding with some future research suggestions.

\section{Literature review and hypothesis development An overview of earnings management}

The financial and accounting literature records a variety of definitions of earnings management. The most widely cited definition is initiated by Schipper (1989), who defined this practice as a volunteer intervention in the external financial reporting process, with the intention of obtaining some private gain. This definition is subject to an opportunistic aspect. It shows that the ultimate objective of earnings management is to manage earnings, i.e., to master accounting standards' workings, using the options and advantages provided, without exceeding the limit of legality, to improve a company's financial situation during a specific period. Earnings management can be led to a signaling objective. Identically to Degeorge et al. (1999), who define earnings management as "the use of managerial discretion to influence the financial information communicated to stakeholders".

Healy (1985) is the first researcher to mention the term accrual in his paper "The effects of bonus schemes on accounting decisions". He noted that the existence of accruals results from the requirements of accounting standard setters. Healy (1985) considers two approaches to manage earnings: controlling accruals or changing accounting policies (real earnings management). Accruals evaluate all the accounting adjustments required to move from a cash basis to an accrual basis accounting. They are composed of all income and expenses recorded in the income statement that did not result in any cash flows during the year. 


\section{Corporate governance and earnings management}

Empirical research has focused for decades on the various factors that influence the quality of results. This attention has focused primarily on accrual-based earnings management. In the context of the importance of corporate governance that has been discussed, several previous studies have investigated whether corporate governance mechanisms affect earnings management practices. The argument regarding the influence of corporate governance mechanisms on earnings management needs to be revisited from the point of view of agency theory, which suggests that there should be a distinct separation between control and ownership. When an organization's managers do not hold ownership, their attitude is influenced by self-interest objectives that are inconsistent with maximizing shareholder and stakeholder wealth and increasing the organization's value (Jensen and Meckling, 1976).

\section{Board of directors' characteristics}

Various corporate governance mechanisms help align managers' and shareholders' interests and limit the agency costs generated by these managers. The key one is the board of directors. In the context of agency theory, Fama and Jensen (1983) stressed that financial transactions must be supervised, and the credibility and validity of these operations are imperative for the board to achieve shareholders' interests while protecting their rights. In general, the board of directors has a multitude of characteristics that can be used to strengthen the overall management of the firm.

\section{Board's size}

The board of directors can be considered one of the most vital internal control mechanisms affecting earnings management. From an agency theory viewpoint, large board size is a tool that reduces agency problems. For example, Ghosh et al. (2010) have shown that a large board size allows taking advantage of a wide range of its members' experiences and provides more monitoring and control over managers' actions.

However, according to Watts's and Zimmerman's (1986) political cost assumption, large firms are likely to have more important boards of directors and that such companies will be more politically visible. On the other hand, Beasley (1996) and Dechow et al. (1995) found that as board size increases, there is less effective supervision of managers, and managers tend to manipulate earnings.

Overall, the existing literature reveals that board size measured by the total number of directors negatively impacts earnings management (Adeolu Abata and Oseko Migiro, 2016; Aygun et al. 2014; Ghosh et al. 2010). Based on this, we propose our first hypothesis:

Hypothesis 1.1. There is a significant negative connection between the board of directors' size and the earnings management level of Moroccan listed companies.

\section{CEO's duality}

Stewardship theory and agency theory are the two theoretical explanations for the separation between the CEO and the board's chairman. According to agency theory, accumulating the CEO and chairman positions does not improve the board's effective vigilance over managerial opportunism.

These two functions, performed by different people, reduce asymmetric information and agency costs and improve corporate governance (Fama and Jensen, 1983). Differently, the stewardship theory stipulates that managers are the best directors of firms, and the manager's duality could help promote strong management.

Defenders of the CEO's duality argue that duality should enhance the financial performance of companies because it provides clear leadership to formulate and implement the strategy (Anderson and Anthony, 1986). Critics of the CEO's duality argue that the company's board is dominated by the CEO when there is duality. To guarantee the board's effectiveness, it is essential to separate the chairman and CEO positions. Similarly, several previous studies have shown that CEO's duality limits the effectiveness of the board in monitoring management behavior (Iraya et al. 2015; Jensen, 1993; Lipton and Lorsch, 1992; Molz, 1988; Rajeevan and Ajward, 2019; S. Latif and Abdullah, 2015; Whittington, 1993). Thus, it is expected that the CEO's duality limits the effectiveness of monitoring management behavior in earnings management. Thus, we hypothesize the following: 
Hypothesis 1.2. There is a significant positive interplay between the CEO's duality and the earnings management level of Moroccan listed companies.

\section{Board's independence}

The agency theory stipulates that independent directors add value to firms because of their effective oversight role and thus allow them to better perform their role by minimizing the agency costs, which potentially could lead to conflict (Jensen and Meckling, 1976; Rosenstein and Wyatt, 1990).

In the same vein, Klein (2002) argued that boards dominated by independent directors provide a better breadth of knowledge and experience to the firm and better control and monitor the managers. Other authors (Iraya et al. 2015; Marra et al. 2011; Rajeevan and Ajward, 2019; S. Latif and Abdullah, 2015) confirmed that independent directors' presence and earnings management are negatively correlated.

In contrast, studies have found that board independence has a significant positive impact on earnings management (Adeolu Abata and Oseko Migiro, 2016). Nevertheless, other papers did mention that there is an insignificant correlation between board independence and earnings management (Katmon and Farooque, 2017; Kent et al. 2010; Ramachandran et al. 2015).

Based on these theoretical assumptions, it is expected that the board's independence could create a situation of potential conflict of interest and reduce the governance body's ability to carry out its missions and governance roles. Therefore, our hypothesis state that:

Hypothesis 1.3. There is a significant negative connection between the board's independence and the earnings management level of Moroccan-listed companies.

\section{Audit committee existence}

The ultimate reason for creating an audit committee is to oversee the accounting process and to maintain normal communication between the committee and the internal and external auditors. In addition, this committee is an essential part of the internal ecosystem of any firm because it helps the governance body to achieve the company's goals while protecting shareholders' interests (Fama and Jensen, 1983). Most studies indicate that an audit committee attached to the governance body mitigates the level of earnings management. Indeed, by studying a large sample of 92 U.S. firms under investigation for earnings manipulation between April 1982 and December 1992, Dechow et al. (1995) found that the existence of an audit committee negatively influences earnings manipulation.

Similarly, Klein (2002) confirms that the audit committee's presence reduces earnings management in U.S. firms. Several other researchers also argue that earnings management is less likely in firms with active audit committees (Beasley, 1996; Chen and Zhang, 2014; Marra et al. 2011; Peasnell et al. 2005; Sae-Lim and Jermsittiparsert, 2019). We, therefore, found it suitable to test this hypothesis:

Hypothesis 1.4. There is a significant negative connection between the audit committee's existence and the earnings management level of Moroccan-listed companies.

\section{Audit committee size}

Numerous studies suggest that the audit committee's presence should improve accounting practices (Dezoort, 1998). The complexity of a company's financial system requires a substantial effort from audit committee members. In other words, an audit committee with a large set of members could monitor earnings management. Similarly, Katmon and Farooque (2017) documented that the audit committee could detect and resolve the potential problems in the financial reporting process.

The real influence of audit committee size on earnings management is still a debatable question because of the mixed empirical results. This plurality of conclusions on the effects of this committee is explained by differences in regulatory systems. Each country has different corporate governance codes based on its culture, legal system, and politics.

Some researchers have found a positive relationship (Adeolu Abata and Oseko Migiro, 2016; He and Yang, 2014). In comparison, others have found a negative connection (Ghosh et al. 2010; Lubis and Adhariani, 2019; Rajeevan and Ajward, 2019; Sierra García et al. 2012). To be consistent with this reasoning, our study hypothesizes the following: 
Hypothesis 1.5. There is a significant negative connection between the audit committee size and the earnings management level of Moroccan-listed companies.

6. Audit committee independence

An audit committee's existence is not necessarily sufficient to mitigate earnings management in some cases. Ensuring the effectiveness of the audit committee's monitoring role depends on the committee's organizational structure. Indeed, Vicknair et al. (1993) argue that the audit committee's independence is one of the vital elements that affect management in companies because the presence of independent auditors affiliated within the committee helps in absorbing managers' pressure on internal auditors.

Many researchers have studied the relationship between audit committee independence and accrualbased earnings management. These studies find that independent auditors who do not have any personal incentives are considered more effective monitors because they can constrain the managers' discretion (Chen and Zhang, 2014; Davidson et al. 2005; Ghosh et al. 2010; Rajeevan and Ajward, 2019; Sharma and Kuang, 2014; Xie et al. 2003; S. Latif and Abdullah, 2015).

To this end, the present study hypothesizes that independent auditors' existence can mitigate any company earnings management level. This assumption is consistent with the reasoning above. Also, it is essential to highlight that most recent papers have found a negative association between this pair of variables.

Hypothesis 1.6. There is a significant negative interplay between the audit committee independence and the earnings management level of Moroccan listed companies.

\section{Audit committee expertise}

Audit committee expertise is used to assess the committee's ability to identify financial flaws and manipulations, such as earnings management. Financial research is very necessary for audit committee members to maintain focus on the company's financial reports. McMullen and Raghunandan (1996) argue that companies are less likely to face financial problems when financial experts are present on their audit committees.

Auditors with financial expertise are in a superior position to monitor the financial statements' integrity. They have similar analytical techniques to external auditors in terms of processing financial reports, which has a positive impact on their oversight judgment, requires better quality audits, and helps facilitate effective communication with internal and external auditors on oversight issues (Alzeban and Sawan, 2015; Lary and Taylor, 2012). The experience factor is one of the most important determinants of detecting and understanding earnings management strategies.

Literature examining audit committee expertise, such as (Chen and Zhang, 2014; He and Yang, 2014; Lubis and Adhariani, 2019; Sharma and Kuang, 2014; Xie et al. 2003) reveal that an audit committee with financial experts mitigates earnings management. Consequently, our hypothesis was established according to the explanation above:

Hypothesis 1.7. There is a significant negative connection between the audit committee expertise and the earnings management level of Moroccan-listed companies.

\section{Gender diversity}

Recently, one aspect of governance structure that has received increasing attention is gender diversity. It is common in business management that women are less risks taking managers, especially in financial decisions. Systematically that means that they are not likely to engage in unethical behavior to gain private benefits (Khazanchi, 1995; Powell and Ansic, 1997).

Previous research papers have studied this factor using the number or percentage of female directors actively operating within the governance body by examining the relationship between their presence within the board composition and earnings management (Alqatan, 2019; Debnath and Roy, 2019; Kyaw et al. 2015; Mnif and Cherif, 2020; Triki Damak, 2018). These researchers showed that earnings 
manipulation is lower in companies with higher female board representation. They argued that differences in gender, moral values, and female incentives have important implications for financial reporting quality and corporate governance. We, therefore, propose our eighth hypothesis:

Hypothesis 1.8. There is a significant negative relationship between gender diversity and the earnings management level of Moroccan listed companies.

\section{Ownership structure characteristics}

The ownership structure is seen as another vital factor linked to a variety of accounting issues such as corporate financial performance, earnings quality, and earnings management. Theoretical arguments on the interplay between ownership structure and accounting information are based on Jensen's and Meckling's (1976) theory. These authors have argued that the separation of ownership and control leads to agency costs because of the highly present self-serving behavior of managers, leading to a conflict of interest with the original shareholders. The connection between ownership structure and earnings management has attracted important attention in the recent financial literature. Different dimensions of ownership structure have been tested in previous studies.

\section{Ownership concentration}

Ownership concentration could be defined as a measure of large shareholders' existence in a firm (Thomsen and Pedersen, 2000). For Jensen and Meckling (1976), ownership concentration is a vital control mechanism for solving problems between the agent and the principal. However, several authors consider it risky because it allows the largest shareholders to use the firm's resources for their interests. Belhadj et al. (2016) highlighted the positive influence of ownership concentration on discretionary accruals, which are a proxy for earnings management. On the other hand, Waweru and Riro (2013) showed that ownership concentration impedes earnings quality because it increases discretionary accruals. In this sense, many studies have shown the positive effect of ownership concentration on earnings management level (Adeolu Abata and Oseko Migiro, 2016; Belhadj et al. 2016; Waweru and Riro, 2013). On this basis, we hypothesis the following idea:

Hypothesis 2.1. There is a significant positive connection between ownership concentration and earnings management level of Moroccan listed companies.

\section{Institutional ownership}

Institutional investors play an active role in supervising managerial discretion and enhancing information efficiency in worldwide capital markets (Balsam et al. 2003).

Indeed, Carleton et al. (1998) argue that a greater presence of institutional investors increases monitoring efficiency and owners' capabilities in controlling firms. Therefore, this type of ownership is an important governance mechanism for monitoring in depth the behavior of managers. In the same vein, Sáenz González and García-Meca (2014) uphold the argument that an increase in institutional ownership should positively impact a firm's behavior, as managers would be discouraged from doing earnings management due to pressure from institutional investors. In the same path, several authors have shown a negative connection between institutional investors' presence and earnings management (Jouber and Fakhfakh, 2012; Lel, 2013; Shah and Shah, 2014). Thus, we could propose the following hypothesis:

Hypothesis 2.2. There is a significant negative interplay between institutional ownership and the earnings management level of Moroccan-listed companies.

\section{Managerial ownership}

Agency theory proposes that when executives do not hold shares in the firm they manage or only hold a small percentage of that enterprise, their actions are influenced by their personal motivations, which could differ from the firm's main financial goals and, therefore, shareholders' interests, making of earnings management a common practice inside the firm (Fama, 1980; Fama and Jensen, 1983; Jensen and Meckling, 1976). Specifically, if the managerial part of the firm's capital presents a significant portion of the CEOs' personal investments, they would be more likely to gradually align their personal interests with those of shareholders and exhibit lower discretionary accruals (Jung and Kwon, 2002). On the other hand, Warfield et al. (1995) empirically demonstrated that managerial ownership is 
contrarily related to discretionary accruals. In this sense, Anwar and Buvanendra (2019); Ekpulu and Omoye, (2018), and Saleem Salem Alzoubi (2016) found a significantly negative correlation between managerial ownership and earnings management.

Hypothesis 2.3. There is a significant negative connection between managerial ownership and the earnings management level of Moroccan-listed companies.

\section{Family ownership}

Family ownership brings together the founder or family members (i.e., an employee or a manager as a group) (Villalonga and Amit, 2006). Studies on the effect of family ownership control are the subject of a lively debate. Two different views emerge from this dichotomy. The first point of view stipulates that a founding family with a long-term vision will limit managers' ability to manipulate earnings. In contrast, this configuration could potentially lead to the expropriation of minority shareholders' interests (Jaggi et al. 2009). In other words, family businesses are more likely to deal with agency problems arising from the conflict between the major block-holders and the minor shareholders.

Theoretically, a high level of family ownership can amplify agency problems due to the expropriation of minority shareholders' interests, which lead in consequence to a positive influence on earnings management, as shown by several studies (La Rosa et al. 2020; Sadjiarto et al. 2019; $\underline{\text { Saleem Salem }}$ Alzoubi, 2016). We, therefore, propose our final conceptual hypothesis:

Hypothesis 2.4. There is a significant positive connection between family ownership and the earnings management level of Moroccan listed companies.

\section{Research methodology}

Following a pure positivist epistemological posture as defined by Thiétart et al. (2014), and adopting a fully quantitative research methodology. We conducted this study based on a balanced data panel of 27 firms over three years from 2016 to 2018 , for a total of 81 observations with approximately 14 corporate governance characteristics for each observation. This study focuses on generating new evidence regarding the impact of corporate governance mechanisms on earnings management in Morocco, using more recent data than previous papers. The data is collected manually from yearly reports, financial statements, reference documents available on the CSE website and the Moroccan Capital Markets Authority (MCMA) online platform. After assembling the data panel with Microsoft EXCEL 2019, we used Stata 16 and EViews 11 to perform the empirical analyses.

\section{Sample selection}

Our study population consists of all listed firms on the Casablanca Stock Exchange (CSE) between 2016 and 2018, except 32 firms with missing data and two other companies that ended their stock market journey during the study period. All financial firms were excluded from the sample due to their distinct regulatory environment, especially in terms of corporate governance and accounting methods, making it challenging to estimate discretionary accruals (Davidson et al. 2005; Katmon and Farooque, 2015; Mnif and Cherif, 2020). The following table presents the process of sampling and selection of the listed companies in our final sample:

Table 1. Sample selection process

\begin{tabular}{lc}
\hline Sample selection & Number \\
\hline Total number of companies listed on the CSE in 2018 & 76 \\
\hline Unlisted companies at 2015 & 2 \\
\hline = Total number of companies attending during 2015-2018 & 74 \\
\hline Companies operating in the financial sector & 15 \\
(6 banks) & \\
(5 insurances) & \\
(4 financing companies) & 32 \\
\hline Companies with no governance information & 27 \\
\hline = Final sample
\end{tabular}

Source: Authors' own. 
In terms of sector types, building and construction materials, food processing and production, and distribution sectors are the sectors with the highest percentage of the sample, with a percentage about $15 \%$ (4 companies for each sector) with a weight of $44.44 \%$ of the final sample. Followed by participation and real estate promotion, representing $11 \%$ of the sample ( 3 companies). The petroleumgas and lubricants and the trade and transport sectors represent $7 \%$ of the sample ( 2 companies). In contrast, the remaining sectors represent the smallest proportion, respectively $4 \%$ of the sample companies.

\section{Model design}

The current study uses earnings management as a dependent variable since it is a typical proxy of earnings management in the accounting literature. Discretionary accruals will be used as a measure for earnings management, and the magnitude of discretionary accruals is included as estimated residuals from the modified Jones model (Xie et al. 2003; Katmon and Farooque, 2017, Ben Ayed-Koubaa, 2010).

The first step in calculating discretionary accruals is to estimate total accruals. Total accruals are defined in this study as the difference between the net income of a year and the cash flow from operating activities scaled by the lagged total assets.

$$
\mathrm{TACC}_{\mathrm{it}}=\mathrm{NI}_{\mathrm{it}}-\mathrm{CFO}_{i t}
$$

Where the variable $\mathbf{T A C C}$ it refers to the total accruals of firm $i$ at time $t$, the variable $\mathbf{N I}_{\mathbf{i t}}$ is the net income of firm $i$ at time $t$, and $\mathbf{C F} \mathbf{O}_{i t}$ refers to the cash flow from operations.

Total accruals are separated into discretionary (abnormal) accruals generated by earnings management and non-discretionary accruals. Non-discretionary accruals are normal for the company and fluctuate with its level of performance and business strategy, and other economic factors, while discretionary accruals are creatively generated by earnings management during the preparation of financial statements using accounting policy choices and accounting estimates (Healy, 1985).

In a second step, we will calculate the discretionary accruals according to the model of Dechow et al. (1995), which is presented as follows:

$$
\frac{T_{A C C_{i, t}}}{A_{i, t-1}}=a_{1}\left(\frac{1}{A_{i, t-1}}\right)+a_{2}\left(\frac{\Delta R E V_{i, t}-\Delta R E C_{i, t}}{A_{i, t-1}}\right)+a_{3}\left(\frac{P P E_{i, t}}{A_{i, t-1}}\right)+\varepsilon_{i, t}
$$

Where the variable $\triangle R E V_{i, t}$ presents the revenue's changes (Credit Sales) for the company (i) during period (t); $\triangle R E C_{i, t}$ is the changes in accounts receivable for the company (i) during period ( $\mathrm{t}$ ); $P P E_{i, t}$ is Property, Plant and Equipment; the variable $A_{i, t-1}$ is the total assets for the enterprise (i) at the period $(\mathrm{t}-1)$; and $\varepsilon_{i, t}$ is a random error term.

In this step, discretionary accruals $\left(\boldsymbol{D} \boldsymbol{A C} \boldsymbol{C}_{\mathbf{i}, \mathbf{t}}\right)$ are obtained by the difference between total accruals and non-discretionary accruals estimated using the parameters of the modified Jones model of Dechow et al. (1995) as follows:

$$
\frac{\mathrm{DACC}_{\mathrm{i}, \mathrm{t}}}{\mathrm{A}_{i, t-1}}=\frac{T A C C_{\mathrm{i}, \mathrm{t}}}{\mathrm{A}_{i, t-1}}-\left[\alpha_{1}\left(\frac{1}{\mathrm{~A}_{i, t-1}}\right)+a_{2}\left(\frac{\Delta R E V_{i, t}-\Delta R E C_{i, t}}{\mathrm{~A}_{i, t-1}}\right)+a_{3}\left(\frac{P P E_{i, t}}{\mathrm{~A}_{i, t-1}}\right)\right]
$$

Since we are looking for the impact of corporate governance mechanisms on earnings management, absolute values are used to measure earnings management, whether earnings management is used to decrease or increase earnings, thus capturing the combined effect of both types of earnings management (Ben Ayed-Koubaa, 2009; Katmon and Farooque, 2017; Xie et al. 2003). Thus, our study examines the magnitude of earnings management, not its direction.

Our model is therefore as follows:

$$
\begin{aligned}
(\text { DAAC })_{i, t}= & \alpha_{0}+\alpha_{1}(\text { SIZE })_{i, t}+\alpha_{2}(\text { DUAL })_{i, t}+\alpha_{3}(\text { INDEP })_{i, t}+\alpha_{4}(\text { COM })_{i, t} \\
& +\alpha_{5}(\text { ACSIZE })_{i, t}+\alpha_{6}(\text { ACIND })_{i, t}+\alpha_{7}(\text { ACEXP })_{i, t}+\alpha_{8}(\text { GENDER })_{i, t} \\
& +\alpha_{9}(\text { CON })_{i, t}+\alpha_{10}(\text { INST })_{i, t}+\alpha_{11}(\text { MANG })_{i, t}+\alpha_{12}(\text { FAM })_{i, t} \\
& +\alpha_{13}(\text { In_size })_{i, t}+\alpha_{14}(\text { ROA })_{i, t}+\alpha_{15}(\text { Profitability })_{i, t}+\mu_{i}+v_{t}+\varepsilon_{i, t}
\end{aligned}
$$


Table 2. Description of explanatory and control variables

\begin{tabular}{|c|c|c|c|c|}
\hline Variables & Acronyms & Measures & Signs & References \\
\hline \multicolumn{5}{|c|}{ Board of director's characteristics } \\
\hline Board's size & SIZE & $\begin{array}{l}\text { The number of directors inside the } \\
\text { governance body }\end{array}$ & $(-)$ & $\frac{\underline{\text { Aygun et al. (2014); } ; \text { Adeolu Abata and }}}{\frac{\text { Oseko Migiro (2016); Ghosh et al. }}{\underline{(2010)}}}$ \\
\hline CEO's duality & DUAL & $\begin{array}{c}\text { Binary variable worth } 1 \text { " when there is a } \\
\text { duality and "0" when there is a separation } \\
\text { of functions. }\end{array}$ & $(+)$ & $\frac{\text { Forker (1992) }}{\underline{(2015)} ; \underline{\text { S. Laya et al. (2015) }}}$ \\
\hline $\begin{array}{c}\text { Board's } \\
\text { independence }\end{array}$ & INDEP & $\%$ of independent directors. & $(-)$ & $\begin{array}{l}\frac{\text { Marra et al. (2011) }}{\text { Abdullah (2015); S. Latif and }} ; \underline{\text { raya et al. (2015) }} ; \\
\underline{\text { Rajeevan and Ajward (2019) }}\end{array}$ \\
\hline $\begin{array}{c}\text { Existence of an } \\
\text { audit committee }\end{array}$ & COM & $\begin{array}{l}\text { Binary variable coded } 1 \text { if the firm has an } \\
\text { audit committee and } 0 \text { otherwise. }\end{array}$ & $(-)$ & $\begin{array}{l}\frac{\text { Beasley (1996); Peasnell et al. (2005); }}{\text { Sae-Lim and Jermsittiparsert (2019); }} \\
\text { Marra et al. (2011) }\end{array}$ \\
\hline $\begin{array}{c}\text { Audit committee } \\
\text { size }\end{array}$ & ACSIZE & $\begin{array}{c}\text { The total number of permanent auditors on } \\
\text { the audit committee. }\end{array}$ & $(-)$ & $\frac{\text { Rajeevan and Ajward (2019); }}{\text { Lubis and }}$ \\
\hline $\begin{array}{l}\text { Audit committee } \\
\text { independence }\end{array}$ & ACIND & $\begin{array}{l}\% \text { of independent directors inside the audit } \\
\text { committee. }\end{array}$ & $(-)$ & $\begin{array}{l}\frac{\text { Sharma and Kuang (2014); Kent et al. }}{(2010) ; \text { S. Latif and Abdullah (2015) }} \\
\underline{\text { Rajeevan and Ajward (2019) }}\end{array}$ \\
\hline $\begin{array}{c}\text { Audit committee } \\
\text { expertise }\end{array}$ & ACEXP & $\begin{array}{l}\text { A dichotomous variable takes the value } 1 \\
\text { if there is an accounting/financial } \\
\text { professional inside the audit committee } \\
\text { and } 0 \text { otherwise. }\end{array}$ & $(-)$ & $\frac{\text { He and Yang (2014); Sharma and Kuang }}{\text { (2014); Lubis and Adhariani (2019) }}$ \\
\hline $\begin{array}{l}\text { Gender } \\
\text { diversity }\end{array}$ & GENDER & $\%$ of women on the board of directors. & $(-)$ & $\begin{array}{l}\frac{\text { Mnif and Cherif (2020); Kyaw et al. }}{\text { (2015); Alqatan (2019); }} \text { Debnath and } \\
\underline{\text { Roy (2019); Triki Damak (2018) }}\end{array}$ \\
\hline \multicolumn{5}{|c|}{ Ownership structure characteristics } \\
\hline $\begin{array}{l}\text { Ownership } \\
\text { concentration }\end{array}$ & $\mathrm{CON}$ & (1) absence; (2) minority; (3) majority & $(+)$ & $\begin{array}{l}\frac{\text { Waweru and Riro (2013); }}{\text { and Oseko Migiro (2016) }} \text {; Belhadj et al. } \\
\text { (2015) }\end{array}$ \\
\hline $\begin{array}{c}\text { Institutional } \\
\text { ownership }\end{array}$ & INST & $\%$ of capital held by institutional investors & $(-)$ & $\frac{\text { Jouber and Fakhfakh (2011); Lel (2013); }}{\text { Shah and Shah (2014) }}$ \\
\hline $\begin{array}{c}\text { Managerial } \\
\text { ownership }\end{array}$ & MANG & $\%$ of shares held by directors. & $(-)$ & $\begin{array}{c}\frac{\text { Saleem Salem Alzoubi (2016); Ekpulu }}{\text { and Omoye (2018) }} \\
\text { and }\end{array}$ \\
\hline $\begin{array}{c}\text { Family } \\
\text { ownership }\end{array}$ & FAM & $\%$ of shares held by family members. & $(+)$ & $\begin{array}{l}\text { Sadjiarto et al. (2019); Saleem Salem } \\
\text { Alzoubi (2016); La Rosa et al. (2020) }\end{array}$ \\
\hline \multicolumn{5}{|c|}{ Control variables } \\
\hline ROA & ROA & $R O A=\frac{\text { Net income }}{\text { Total assets }}$ & & Sáenz González and García-Meca (2014) \\
\hline Profitability & PROF & $T P=\frac{\text { Net income }}{\text { Revenues }}$ & & Katmon and Farooque (2015) \\
\hline Company size & LN_SIZE & The natural logarithm of total assets. & & $\frac{\text { Shah and Shah (2014); }}{(2005)}$ Davidson et al. \\
\hline
\end{tabular}

Source: Authors' own.

\section{Results and discussions}

In order to establish an empirical model in the Moroccan context, we are going to present in this section our empirical results.

\section{Descriptive statistics}

Our descriptive statistics are presented in the following table. 
Table 3. Summary of descriptive statistics

\begin{tabular}{cccccc}
\hline Variables & N & Mean & $\begin{array}{c}\text { Standard } \\
\text { deviation }\end{array}$ & Min & Max \\
\hline MJM_1995 & 81 & 0,05712 & 0,044851 & 0,0002875 & 0,2476018 \\
SIZE & 81 & 7,938 & 2.624 & 3 & 14 \\
DUAL & 81 & 0,593 & 0.494 & 0 & 1 \\
INDEP & 81 & $14,626 \%$ & 0.234 & 0 & $80 \%$ \\
COM & 81 & 0,84 & 0.369 & 0 & 1 \\
ACSIZE & 81 & 2,667 & 1.5 & 0 & 6 \\
ACIND & 81 & $21,893 \%$ & 0.37 & 0 & 1 \\
GENDER & 81 & $10,585 \%$ & 0.099 & 0 & $33,333 \%$ \\
CON & 81 & 2,617 & 0.561 & 1 & 3 \\
INST & 81 & $58,629 \%$ & 0.305 & 0 & $99,72 \%$ \\
MANG & 81 & $11,10 \%$ & 0.198 & 0 & $57,01 \%$ \\
FAM & 81 & $14,79 \%$ & 0.261 & 0 & $100 \%$ \\
LN_SIZE & 81 & 22,218 & 1.375 & 19.402 & 25.427 \\
PROF & 81 & $7,948 \%$ & 0.107 & $34,976 \%$ & $28,98 \%$ \\
ROA & 81 & $3,628 \%$ & 0.044 & $-16,513 \%$ & $15,748 \%$ \\
\hline
\end{tabular}

Source: Authors' own (Stata 16).

Table 3 shows that the average board size (SIZE) is 7.938. This result is in line with the requirements of Law No. 17-95, updated by Law No. 20-05, relating to the public limited companies, which stipulate that listed companies' board size must be between 3 and 15 directors. Nevertheless, companies undergoing restructuring operations benefit from a higher quota if they are listed. However, the mean value of audit committee independence is low at $21.89 \%$, which indicates that it increases the possibility for executives to engage in earnings management practices. These results are confirmed by Saleh et al. $\underline{(2005)}$.

On the other hand, the absence of audit committees in some Moroccan listed companies could be the potential reason for the insignificant regression results related to the characteristics of audit committees in Moroccan listed companies compared to other countries, knowing that the regulatory framework states that every listed firm must have an audit committee. For ownership structure, family ownership (FAM) followed an upward trend over the three years of the study, with an average of $14.79 \%$, a minimum of 0 , and a maximum of $100 \%$. Empirical studies suggest that a significant percentage of family ownership will create agency conflicts and higher earnings management.

The correlation matrix reveals a very high correlation up to 1 between COM and ACEXP, in other words, an identical and perfect correlation. It alerts us of the existence of a potential multicollinearity problem. An additional test of Vector Inflation Factor (VIF) shows the validation of our predictions on the existence of the problem mentioned above. Therefore, the elimination of one of the variables objects of the problem is primordial and imperative. Therefore, the ACEXP variable has been eliminated from the study because of the COM variable's high representativeness and importance. 
Table 4. Correlation Matrix and multicollinearity test

\begin{tabular}{|c|c|c|c|c|c|c|c|c|c|c|c|c|c|c|c|c|c|}
\hline & MJM_1995 & SIZE & DUAL & INDEP & сом & ACSIZE & ACIND & GENDER & ACEXP & CON & INST & MANG & FAM & LN_SIZE & PROF & RPA & VIF \\
\hline MJM_1995 & 1 & & & & & & & & & & & & & & & & \\
\hline SIZE & -0.0171 & 1 & & & & & & & & & & & & & & & 1.77 \\
\hline DUAL & $-\mathbf{0 . 0 8 5 7}$ & -0.139 & 1 & & & & & & & & & & & & & & 1.70 \\
\hline INDEP & -0.114 & -0.125 & $0.275^{*}$ & 1 & & & & & & & & & & & & & 3.47 \\
\hline COM & 0.168 & 0.126 & -0.0203 & $-0.244 *$ & 1 & & & & & & & & & & & & 4.45 \\
\hline ACSIZEE & 0.108 & $0.321 * *$ & -0.185 & $-0.232 *$ & $0.782 * * *$ & 1 & & & & & & & & & & & 4.03 \\
\hline ACIND & -0.0770 & 0.0898 & $0.307 * *$ & $0.505 * * *$ & $0.260 *$ & 0.0835 & 1 & & & & & & & & & & 3.47 \\
\hline GENDER & $-\mathbf{0 . 0 3 7 7}$ & -0.145 & $0.343^{* *}$ & $0.376^{* * * *}$ & : 0.0929 & 0.0900 & 0.178 & 1 & & & & & & & & & 1.84 \\
\hline ACEXP & 0.168 & 0.126 & -0.0203 & $-0.244^{*}$ & 1 & $0.782 * * *$ & $0.260 *$ & 0.0929 & 1 & & & & & & & & - \\
\hline COM & -0.0287 & -0.00910 & -0.0735 & -0.216 & -0.119 & -0.0496 & -0.163 & 0.183 & -0.119 & 1 & & & & & & & 2.10 \\
\hline INST & $0.254 *$ & 0.198 & $-0.344 * *$ & $-0.526 * * *$ & * 0.131 & $0.305^{* * *}$ & $-0.230 *$ & -0.0932 & 0.131 & $0.400 * * * *$ & 1 & & & & & & 3.12 \\
\hline MANG & -0.149 & $-0.260 *$ & 0.189 & $0.756^{* * * *}$ & $-0.227 *$ & $-0.252 *$ & $0.349 * *$ & $0.224 *$ & $-0.227 *$ & $-0.344 * *$ & $-0.665 * * *$ & 1 & & & & & 4.71 \\
\hline FAM & -0.0410 & $-0.367 * * *$ & $0.291 * *$ & $0.510^{* * *}$ & $-0.246^{*}$ & $-0.408 * * *$ & 0.0743 & 0.204 & $-0.246 *$ & -0.0514 & $-0.651 * * *$ & $0.584 * * *$ & 1 & & & & 2.78 \\
\hline LN_SIZE & 0.0760 & $0.400 * * *$ & -0.167 & -0.209 & 0.160 & $0.254 *$ & -0.100 & -0.207 & 0.160 & $0.280 *$ & 0.203 & $-0.243^{*}$ & $-0.238^{*}$ & 1 & & & 2.33 \\
\hline PROF & 0.193 & 0.116 & $-0.255^{*}$ & -0.0623 & $0.222^{*}$ & $0.257 *$ & -0.0208 & -0.0512 & $0.222 *$ & -0.0942 & -0.0594 & -0.119 & -0.104 & $0.455^{* * *}$ & 1 & & 3.47 \\
\hline ROA & $0.276^{*}$ & 0.144 & $-0.233^{*}$ & -0.0673 & $0.337 * *$ & $0.371^{* * * *}$ & 0.0182 & 0.119 & $0.337 * *$ & $-0.290 * *$ & -0.0491 & -0.0210 & -0.211 & 0.0974 & $0.684 * * *$ & 1 & 3.13 \\
\hline
\end{tabular}




\section{Discretionary accruals estimation}

Table 5 presents the regression results for MJM_1995. With a Fisher statistic of (8.138) significant at a $1 \%$ level, we could conclude that the model is well specified. In contrast, the coefficient of determination highlights the imperfect goodness of fit. However, this does not represent an obstacle for our study since we are interested in studying the effects of governance mechanisms on earnings management and not the reliability test of the MJM_1995 regression. Besides, it should be noted that this model does not contain a constant, which may explain the results obtained. Thus, the p-values show that the model is correctly specified, and the variables are significant except for the term 2 variable.

The estimated coefficient for term 2 that attempts to measure the difference between the variation in revenue and the change in accounts receivable is insignificant. Contrary to the theoretical stipulations, table 5 shows the lack of importance of accounting policies related to accounts receivable in CSE-listed companies since the inclusion of this variable does not significantly improve the model fit and the representativeness of the coefficients. However, the probability associated with the term 1 coefficient is significant at the $5 \%$ level, while term 3 has a significant variation at the $1 \%$ level.

Table 5. Estimation of MJM_1995

\begin{tabular}{|c|c|c|c|c|c|c|}
\hline TACC_2 & Coef. & $\begin{array}{l}\text { Standard } \\
\text { deviation }\end{array}$ & t-value & p-value & $\begin{array}{l}{[95 \%} \\
\text { Conf } \\
\end{array}$ & Interval] \\
\hline term1 & -20100000 & 9320000 & -2.16 & 0.034 & -38600000 & -1540000 \\
\hline term2 & -0.026 & 0.083 & -0.32 & 0.753 & -0.192 & 0.139 \\
\hline term3 & -0.064 & 0.021 & -3.11 & 0.003 & -0.106 & -0.023 \\
\hline Mean de & & 045 & den & & & 0.070 \\
\hline $\mathbf{R}^{2}$ & & 0.238 & ations & & & 81.000 \\
\hline Fisher-tes & & 8.138 & & & & 0.000 \\
\hline
\end{tabular}

Where,

Source: Authors' own (Stata 16).

\section{Tacc_2 = (NI-CFO) /l.Totalassets Term1 = 1/l.Totalassets;}

\author{
Term2 $=(\triangle R E V-\triangle R E C)$ /l.Actiftotal ; \\ Term3 = PPE/l.Totalassetsl.
}

\section{Main results and findings}

This study used a panel data methodology to study the relation between earnings management and corporate governance mechanisms. For our part, we chose to use the Ordinary Least Squares (OLS) method. Table 6 shows that the OLS regression results have a significant Fisher test probability at a 1\% level, indicating that our model is well specified. The results show that only three variables are significant at a $1 \%$ level, including INST, FAM, and ROA, under a coefficient of determination of $29.2 \%$. In terms of autocorrelation, we used the Durbin-Watson test. This test allows us to verify the existence of autocorrelation of the first order errors. It is based on the estimation of a first-order autoregressive model for the estimated residuals. The result of this test is not conclusive (interval of doubt) because its value is within the interval (dL1.222 and dU1.913) at the $1 \%$ significance level according to the Durbin-Watson Significance Table. To test the homoscedasticity hypothesis, we used the Breusch-Pagan/Cook-Weisberg test, which showed high significance, leading us to reject the null hypothesis, based on the idea that the variance of error terms is constant, thus, a heteroscedasticity problem.

Similarly, the residuals normality test frequently used in the empirical literature by Jarque-Bera provides information on the residuals' non-normality with a significant probability at the $1 \%$ threshold. Adding to this, the fact that the Shapiro-Wilk test carried out using Stata 16 confirms the same results of the Jarque-Bera test, a probability of less than 5\% of this test leads us to reject the null hypothesis, which stipulates the existence of a normal variation. Finally, we tested the residual autocorrelation problem's presence through the Wooldridge test of the first-order autocorrelation. This test recommended that we reject the null hypothesis concerning the absence of a first-order autocorrelation 
between the error terms and our model's explanatory variables. As a result, the OLS model suffers from violations of these assumptions of normality of residuals, homogeneity, and autocorrelation absence. We have determined that the random effects model is the most appropriate to our dataset using the Hausman test on Stata 16, which showed a $\left(\chi^{2}=10.39 ; \mathrm{p}=0.7333\right)$ accepting the specification's null hypothesis.

It appeared that the Wald test indicates the existence of some heteroscedasticity between the sample individuals, as the probability is significant at the $1 \%$ level, which leads us to reject the null hypothesis that the panel data is homoscedastic. Therefore, we must indeed take heteroscedasticity into account for our regression to be theoretically and empirically valid. We directly correct this problem on the EViews software by choosing the EGLS method, which considers the existing heteroscedasticity in our model. With a coefficient of determination of $53.87 \%$, our model has a good quality of fit with an adjusted coefficient of determination of $44.08 \%$ and a highly significant Fisher's test probability, which indicates the excellent degree of specification of our final model excluding the variable experience of the audit committee, that presented a perfect correlation with the variable existence of the audit committee, which contributes to the integration of multicollinearity effects.

The Durbin-Watson autocorrelation test for the EGLS regression reported in the following table is still inconclusive because the value of 1.79 is within the range of the tabulated values of (dL1.222 and dU1.913). The value 1.79 is close to 2 , which leads us to conclude that our model almost qualifies for non-autocorrelation of errors. These results are expected because we are in the presence of a timedependent model. Thus, the residuals' normality diagnosis by the Jarque-Bera method indicates that they have a normal distribution because of the insignificant probability (above 5\%), which leads us to accept the null hypothesis of residuals normality.

Finally, our model shows promising validity signs. Therefore, the results from the EGLS estimator are reliable and empirically valid than other methods' estimators.

Table 6. Regression results

\begin{tabular}{ccccc}
\hline MJM_1995 & OLS & $\begin{array}{c}\text { Fixed } \\
\text { effects }\end{array}$ & $\begin{array}{c}\text { Random } \\
\text { effects }\end{array}$ & EGLS \\
\hline Constant & $\mathbf{- 0 . 0 6 3}$ & $\mathbf{- 0 . 9 4 5}$ & $\mathbf{- 0 . 0 7 7}$ & $\mathbf{- 0 . 0 0 3 1 1 3 7}$ \\
& $(-0.64)$ & $(-0.76)$ & $(-0.60)$ & $(-0.05032)$ \\
\hline SIZE & $-\mathbf{0 . 0 0 1}$ & $\mathbf{- 0 . 0 1 1}$ & $\mathbf{- 0 . 0 0 1}$ & $\mathbf{- 0 . 0 0 2 5 4 2 *}$ \\
& $(-0.22)$ & $(-0.94)$ & $(-0.21)$ & $(-1.961834)$ \\
\hline DUAL & $\mathbf{0 . 0 1 3}$ & $\mathbf{0 . 0 4 8}$ & $\mathbf{0 . 0 1 2}$ & $\mathbf{0 . 0 1 5 4 0 4 * *}$ \\
& $(1.02)$ & $(1.60)$ & $(0.80)$ & $(2.158989)$ \\
\hline INDEP & $\mathbf{0 . 0 3 6}$ & $\mathbf{0 . 0 3 9}$ & $\mathbf{0 . 0 4 5}$ & $\mathbf{0 . 0 4 0 5 9 2}$ \\
& $(0.90)$ & $(0.19)$ & $(0.89)$ & $(1.973289)$ \\
\hline COM & $\mathbf{0 . 0 3 8}$ & $\mathbf{0 . 0 6 8}$ & $\mathbf{0 . 0 5 6} *$ & $\mathbf{0 . 0 3 0 4 9 4} * *$ \\
& $(1.42)$ & $(1.40)$ & $(1.86)$ & $(2.071305)$ \\
\hline GENDER & $\mathbf{- 0 . 0 6 4}$ & $\mathbf{- 0 . 0 4 5}$ & $\mathbf{- 0 . 0 4 9}$ & $\mathbf{- 0 . 1 0 4 4 1 9 * * *}$ \\
& $(-1.21)$ & $(-0.23)$ & $(-0.77)$ & $(-3.160899)$ \\
\hline INST & $\mathbf{0 . 1 0 0} * * *$ & $\mathbf{0 . 1 1 3}$ & $\mathbf{0 . 0 9 6} * *$ & $\mathbf{0 . 0 8 3 8 4 1 * * *}$ \\
& $(3.71)$ & $(0.67)$ & $(2.83)$ & $(5.854421)$ \\
\hline CON & $\mathbf{- 0 . 0 0 7}$ & $\mathbf{- 0 . 0 3 0}$ & $\mathbf{- 0 . 0 1 1}$ & $\mathbf{0 . 0 0 2 4 2 7}$ \\
& $(-0.62)$ & $(-0.30)$ & $(-0.77)$ & $(0.318922)$ \\
\hline ACSIZE & $\mathbf{- 0 . 0 0 8}$ & $\mathbf{- 0 . 0 2 3} *$ & $\mathbf{- 0 . 0 1 4} *$ & $\mathbf{- 0 . 0 0 5 0 9 8}$ \\
& $(-1.28)$ & $(-1.75)$ & $(-1.85)$ & $(-1.521108)$ \\
\hline ACIND & $\mathbf{- 0 . 0 1 5}$ & $\mathbf{- 0 . 0 3 1}$ & $\mathbf{- 0 . 0 2 4}$ & $\mathbf{- 0 . 0 1 8 7 7 9 *}$ \\
& $(-0.76)$ & $(-0.66)$ & $(-1.01)$ & $(-1.830856)$ \\
\hline MANG & $\mathbf{- 0 . 0 0 5}$ & $\mathbf{0 . 0 9 5}$ & $\mathbf{- 0 . 0 0 3}$ & $\mathbf{- 0 . 0 2 8 3 7 6}$ \\
& $(-0.10)$ & $(0.16)$ & $(-0.05)$ & $(-1.092306)$ \\
\hline & & & & \\
\hline & & &
\end{tabular}




\begin{tabular}{|c|c|c|c|c|}
\hline FAM & $\begin{array}{c}\mathbf{0 . 0 6 6}^{* * *} \\
(2.23)\end{array}$ & $\begin{array}{l}\mathbf{- 0 . 0 1 1} \\
(-0.07)\end{array}$ & $\begin{array}{l}\mathbf{0 . 0 4 4} \\
(1.27)\end{array}$ & $\begin{array}{c}\mathbf{0 . 0 4 9 1 7 7} * * * \\
(3.098801)\end{array}$ \\
\hline LN-SIZE & $\begin{array}{l}\mathbf{0 . 0 0 2} \\
(0.41) \\
\end{array}$ & $\begin{array}{l}\mathbf{0 . 0 4 8} \\
(0.77)\end{array}$ & $\begin{array}{l}\mathbf{0 . 0 0 4} \\
(0.56)\end{array}$ & $\begin{array}{c}\mathbf{- 0 . 0 0 0 3 7 5} \\
(-0.112486)\end{array}$ \\
\hline PROF & $\begin{array}{l}-\mathbf{0 . 0 1 5} \\
(-0.19)\end{array}$ & $\begin{array}{l}-\mathbf{- 0 . 0 4 1} \\
(-0.30)\end{array}$ & $\begin{array}{l}\mathbf{- 0 . 0 2 0} \\
(-0.24)\end{array}$ & $\begin{array}{c}\mathbf{- 0 . 0 0 4 6 6 6} \\
(-0.110491)\end{array}$ \\
\hline ROA & $\begin{array}{c}\mathbf{0 . 4 5 4 * *} \\
(2.45) \\
\end{array}$ & $\begin{array}{l}\mathbf{0 . 1 9 0} \\
(0.85) \\
\end{array}$ & $\begin{array}{l}\mathbf{0 . 3 2 0 *} \\
(1.79) \\
\end{array}$ & $\begin{array}{c}\mathbf{0 . 4 4 3 8 5 1} * * * \\
(3.814927) \\
\end{array}$ \\
\hline $\mathbf{N}$ & 81 & 81 & 81 & 81 \\
\hline $\mathbf{R}^{2}\left(\right.$ Overall $\left.\mathbf{R}^{2}\right)$ & 0.292 & 0.231 & $(0.263)$ & 0.538733 \\
\hline $\mathbf{R}^{2}$ Ajusté & 0.142 & - & - & 0.440889 \\
\hline Chi-square & - & - & 17.018 & - \\
\hline F-test & $1.947 * *$ & 0.860 & - & $5.506 * * *$ \\
\hline Durbin-Watson stat & $\mathbf{1 . 3 0 9 1 0 7}$ & - & - & 1.794313 \\
\hline Chi (2) de Breusch-Pagan & $43.83 * * *$ & - & - & - \\
\hline Jarque-Bera des résidus & $38.09548 * * *$ & - & - & $4.662918^{*}$ \\
\hline $\begin{array}{l}\text { Probability of Wald test } \\
\qquad\left(\chi^{2}=27\right)\end{array}$ & - & - & 0.0000 & - \\
\hline (p-value) de Shapiro-Wilk & 0.00109 & - & - & - \\
\hline Wooldridge-test & $6.237 * *$ & - & - & - \\
\hline \multicolumn{5}{|c|}{$\begin{array}{c}t \text {-statistics in brackets. } \\
* * * p<1 \%, * * p<5 \%, * p<10 \%\end{array}$} \\
\hline
\end{tabular}

Source: Authors' own (Stata 16 and EViews 11).

The findings reveal significant differences in the way corporate governance characteristics constrain earnings management in listed companies on CSE. The overall results of the study will upon be discussed and commented.

The results show that board size has a negatively significant effect on the magnitude of discretionary accruals $(\beta=-0.002542 ; \mathrm{p}=0.0540)$. This result is identical to the findings of Adeolu Abata and Oseko Migiro (2016), Aygun et al. (2014), Ghosh et al. (2010), and Xie et al. (2003), who suggested that a large number of directors on the board would most likely eliminate the use of accruals to manipulate earnings. Indeed, the board members' overcrowding can easily control and monitor CEOs' actions because of the overall enhanced board's skills and experience. To this end, our (hypothesis 1.1) was therefore supported.

In terms of the CEO's duality, our findings show that this variable can only support the idea that CEOs who also chair the board of directors can be highly involved in earnings management $(\beta=0.015404$; $\mathrm{p}=0.0345$ ). This result is in line with the arguments of Dechow et al. (1996), Forker (1992), Iraya et al. (2015), and S. Latif and Abdullah (2015), who postulated that the presence of a single figurehead holding both positions could undermine best corporate governance practices. Thus, top management perceives the CEO as having more leeway. Since listed companies have heavy operations and accounting records, the CEO's duality would imply that the CEO controls a large volume of information. This may be a vehicle to produce fraudulent financial statements and manage earnings to reflect a good corporate image. Our (hypothesis 1.2), stating that CEO duality positively impacts earnings management, is therefore accepted.

The findings revealed that the independence of the governance body is positively correlated with earnings management $(\beta=0.040592 ; p=0.0527)$. Our results are consistent with those of Adeolu Abata and Oseko Migiro (2016). Indeed, independent directors' appointment allows the firm to benefit from a greater breadth of their knowledge and experiences. However, this does not demonstrate that the board of directors' independence reduces earnings management's impact. The presence of independent directors on the governance body can be a way to legitimize the structure of its composition to dissuade the financial markets on the quality of supervision within the company. In different words, it is a tool 
for signaling to the markets through the appointment of independent members to the governance body, since theoretically, their presence contributes significantly to the dissolution of existing coalitions in the governance body. However, for their presence to be effective, the percentage of these directors should not exceed the first third of the board of directors' size, according to the recommendations of Law No. 20-19. This may explain why their presence will positively impact earnings management (the average board independence is low, with a value of 14.62\%). Our (hypothesis 1.3) is accordingly rejected.

To identify the audit committee's characteristics, we incorporated the audit committee's different attributes, such as their presence, size, and independence. We notice that an audit committee's presence favors earnings management level with $(\beta=0.030494 ; p=0.0422)$. This result is not aligned with our hypothesis 1.4 , which states that an audit committee's presence has a negative impact on earnings management. Our hypothesis is thus rejected. Furthermore, the audit committee size $(\beta=-0.005098$; $\mathrm{p}=0.1330$ ) has a negative but insignificant effect on earnings management. This allows us also to reject (hypothesis 1.5). This result indicates that firms adhere more to the laws' form rather than to their substance. However, the audit committee's independence may play a role in limiting earnings management. It is noted that there is a significant negative relationship between audit committee independence (ACIND) and earnings management $(\beta=-0.018779 ; \mathrm{p}=0.0716)$, in line with (hypothesis 1.6), audit committees that have a higher value of independent directors have lower earnings management. Independent audit committee members provide a greater range of knowledge and experience to the company and enhance its monitoring effectiveness, which reduces the likelihood of corporate failure and financial fraud. However, independent audit committee members are considered effective supervisors because they have no personal incentives and can withstand managerial pressure to maintain independent judgment while constraining discretionary accruals. Also, independent directors have an incentive to maintain their reputation in the marketplace as competent and independent professionals and do not want to be exposed to potential litigation and the loss of their seats on the board.

Our study results also show that women's presence on the board mitigates earnings management ( $\beta=-$ $0.104419 ; \mathrm{p}=0.0024)$. This result is in agreement with those of Alqatan (2019), Debnath and Roy (2019), Kyaw et al. (2015), Mnif and Cherif (2020), and Triki Damak (2018). Indeed, women on the board of directors are more motivated. In general, they have moral values that reduce corporate earnings management because they do not engage in such practices and strategies. Consistent with agency theory, gender diversity indirectly enhances the effectiveness of the governance body in terms of creating shareholder value by reducing agency costs (Dalton et al. 1998; John and Senbet, 1998). However, women's presence in Moroccan listed companies' governance body remains low, with an average of $10.585 \%$. Still, female executives play an important role in ethical financial reporting, even in a maledominated culture. In this regard, a crucial implication of our study is that the decision to appoint females directors to corporate boards should be based on specific criteria (e.g., financial or accounting expertise, business expertise, and control skills) and not the blind and random implementation of gender quotas. Thus, we can confirm our (hypothesis 1.8) that women's presence on the board of directors reduces the level of earnings management.

There is a positive connection between earnings management and institutional ownership through increased discretionary accruals $(\beta=0.083841 ; p=0.0000)$. The reasoning behind this finding can be found in Matsumoto (2002), who argues that institutional investors induce managers to adopt earnings management strategies to avoid unexpected negative earnings and instead provide higher regular earnings. Indeed, institutional investors can act directly on the interplay between earnings management and a firm's activities, reducing and eliminating suspicious earnings. However, another perspective suggests that institutional investors are "transient investors" who focus on short-term results and pressure management to deliver higher and more consistent results. Thus, transitional institutional investors can exchange control for liquidity. Our findings carry an important implication of designating long-term institutional investors rather than transitional institutional investors to increase the possibility of oversight and owners' effectiveness in controlling management behavior and thus discourage 
earnings management. We, therefore, reject (hypothesis 2.2) because the results indicate that institutional ownership is positively linked to the use of discretionary accruals. This finding is consistent with Cornett et al. (2008), Matsumoto (2002), Obigbemi et al. (2016) and S. Latif and Abdullah (2015). We also note the positive effect of family ownership on earnings management $(\beta=0.049177 ; p=0.0029)$. Our results recorded high family ownership shares, with an average of $14.79 \%$ and a maximum of $100 \%$. This can be explained by family members' behavior, who may take advantage of the firm by holding important positions inside the firm. This could give rise to agency conflicts due to the expropriation of minority shareholders' interests and thus favor the level of earnings management. We, therefore, accept our (hypothesis 2.4) that family ownership positively impacts the level of earnings management. Our results confirm those of La Rosa et al. (2020), Sadjiarto et al. (2019) and Saleem Salem Alzoubi, (2016).

The results also indicate that the ownership concentration variable positively impacts earnings management but not significantly $(\beta=0.002427 ; p=0.7508)$. It is noted that ownership concentration is not expected to impact shareholders' perception of accounting earnings and does not impact earnings management. These results corroborate with those of Sáenz González and García-Meca (2014) and Shah and Shah (2014). This allows us to reject our (hypothesis 2.1), which states that ownership concentration has a significant and positive impact on earnings management.

We also note that managerial ownership has a negative but insignificant effect on earnings management level $(\beta=-0.028376 ; p=0.2787)$. These results are consistent with El Moslemany and Nathan (2019), who reported that managerial ownership does not significantly impact the level of earnings management. Therefore, we reject our hypothesis 2.3 , according to which managerial ownership has a significantly negative impact on earnings management.

The coefficient related to firm performance (ROA) is significantly positive for the control variables at the $1 \%$ level, on the earnings management level, and the degree of correlation between MJM 1995 and ROA is 0.276 . This provides information about the increase in performance that may be related to high earnings management. This can be explained by the informational perspective that views earnings management as a signaling tool to financial markets. Managers often manipulate earnings at their discretion to mislead about the firm's economic performance and create wealth for shareholders. However, company size and profitability do not have a significant influence on earnings management.

\section{Conclusion}

This study's main objective is to observe the interplay between Moroccan corporate governance mechanisms and earnings management to improve financial statements' credibility and reduce earnings management activities. The motivation for this study is the contrast between theory and empirical evidence. By studying a panel of 27 listed firms between 2016 and 2018, we have highlighted significant differences in how governance mechanisms impact earnings management.

Most board characteristics are significantly linked to earnings management, except audit committee size. The results show that there are Moroccan listed companies that do not have an audit committee. However, the audit committee's independence is one of the audit committee's vital features, which controls managerial discretion and limits earnings management activities. Our results also show that combining between the $\mathrm{CEO}$ and chairman roles results in high earnings management levels. We also find that board independence promotes earnings management, and the women's presence on the board contributes to a lower earnings management level. The regression results also show that ownership structure characteristics such as family ownership and institutional investors' presence favor earnings management.

This study's findings provide an overview and commentary that can be useful to regulators, standard setters, and researchers in formulating new policies and improving corporate governance practices in listed companies on the CSE, and developing a better framework for all stakeholders involved in financial reporting. 


\section{Limitation and study forward}

This study has some limitations that complicate the generalization of the obtained empirical results. Namely, the total sample size restricted the scope of the study. Unfortunately, the sample size was much smaller than the initial sample, including all listed companies on the CSE. The selection of firms consists of all non-financial listed companies for the period 2016-2018. The study can be conducted across all sectors to address this obstacle and make a comparative approach between listed and unlisted companies to consider other factors more present at small and medium companies. Another limitation of this paper is that the research did not address how discretionary accruals evolve, which allows for the detection of motivational aspects of earnings management. This could be of significant interest for any future research on this topic.

Overall, the potential for further research on this topic is hence infinite. Many small changes can be made to the research model. Adding qualitative variables by interviewing internal auditors to enhance the model's efficiency could lead to significant results to understand the dynamics of this common financial problem. Nevertheless, the current research's results already provide a better understanding of the interplay between governance mechanisms and earnings management.

\section{References}

Adeolu Abata, M., \& Oseko Migiro, S. (2016). Corporate governance and management of earnings: Empirical evidence from selected Nigerian-listed companies. Investment Management and Financial Innovations, 13(2), 189-205. https://doi.org/10.21511/imfi.13(2-1).2016.07

Alqatan, A. (2019). The association between board diversity, earnings management and firm performance in Kuwait: A research agenda. Corporate Governance: Search for the Advanced Practices, 254-274. https://doi.org/10.22495/cpr19p14

Alzeban, A., \& Sawan, N. (2015). The impact of audit committee characteristics on the implementation of internal audit recommendations. Journal of International Accounting, Auditing and Taxation, 24, 61-71. https://doi.org/10.1016/j.intaccaudtax.2015.02.005

Anderson, C. A., \& Anthony, R. N. (1986). The New Corporate Directors: Insights for Board Members and Executives (1st edition). Wiley.

Anwar, H., \& Buvanendra, S. (2019). Earnings Management and Ownership Structure: Evidence from Sri Lanka. Colombo Business Journal, 10(1), 44. https://doi.org/10.4038/cbj.v10i1.42

Aygun, M., Ic, S., \& Sayim, M. (2014). The Effects of Corporate Ownership Structure and Board Size on Earnings Management: Evidence from Turkey. International Journal of Business and Management, 9(12), 123-132. https://doi.org/10.5539/ijbm.v9n12p123

Balsam, S., Krishnan, J., \& Yang, J. S. (2003). Auditor Industry Specialization and Earnings Quality. AUDITING: A Journal of Practice \& Theory, 22(2), 71-97. https://doi.org/10.2308/aud.2003.22.2.71

Baltagi, B. H. (2008). Econometric analysis of panel data (4th ed). John Wiley \& Sons.

Beasley, M. S. (1996). An Empirical Analysis of the Relation between the Board of Director Composition and Financial Statement Fraud. The Accounting Review, 71(4), 443-465.

Belhadj, R., Omrane, A., \& Regaieg, B. (2016). The Effects of Governance Mechanisms on the Financial Information Quality. Communications of the IBIMA, 1-17. https://doi.org/10.5171/2016.187526

Belkebir, B., Daanoune, R., \& Mouallim, I. (2018). Analysis of the Impact of Governance on Performance: Case of Moroccan Banks. International Journal of Innovation and Applied Studies, 23(4), 756-767.

Ben Ayed-Koubaa, H. B. (2009). L'impact des mécanismes internes de gouvernement de l'entreprise sur la qualité de l'information comptable. https://halshs.archives-ouvertes.fr/halshs-00460918

Bowe, C. (2005, August 11). Sullivan gets five years for WorldCom fraud. The Financial Times. https://www.ft.com/content/e754aee4-0a77-11da-aa9b-00000e2511c8

Carleton, W. T., Nelson, J. M., \& Weisbach, M. S. (1998). The Influence of Institutions on Corporate Governance through Private Negotiations: Evidence from TIAA-CREF. The Journal of Finance, 53(4), 1335-1362. https://doi.org/10.1111/0022-1082.00055 
Chen, J. J., \& Zhang, H. (2014). The Impact of the Corporate Governance Code on Earnings Management - Evidence from Chinese Listed Companies: The Impact of the Corporate Governance Code on Earnings Management. European Financial Management, 20(3), 596632. https://doi.org/10.1111/j.1468-036X.2012.00648.X

Cornett, M., Marcus, A., \& Tehranian, H. (2008). Corporate governance and pay-for-performance: The impact of earnings management. Journal of Financial Economics, 87(2), 357-373. https://doi.org/10.1016/j.jfineco.2007.03.003

Dalton, D. R., Daily, C. M., Ellstrand, A. E., \& Johnson, J. L. (1998). Meta-Analytic Reviews of Board Composition, Leadership Structure, and Financial Performance. Strategic Management Journal, 19(3), 269-290.

Davidson, R., Goodwin-Stewart, J., \& Kent, P. (2005). Internal governance structures and earnings management. Accounting \& Finance, 45(2), 241-267. https://doi.org/10.1111/j.1467629x.2004.00132.x

Debnath, D. P., \& Roy, C. (2019). Gender Diversity in Corporate Governance and Earnings Management: An Indian Panorama. Journal of The Gujarat Research Society, 21(3), 31-44.

Dechow, P. M., Sloan, R. G., \& Sweeney, A. P. (1995). Detecting Earnings Management. The Accounting Review, 70(2), 193-225.

Dechow, P. M., Sloan, R. G., \& Sweeney, A. P. (1996). Causes and Consequences of Earnings Manipulation: An Analysis of Firms Subject to Enforcement Actions by the SEC*. Contemporary Accounting Research, 13(1), 1-36. https://doi.org/10.1111/j.19113846.1996.tb00489.x

Degeorge, F., Patel, J., \& Zeckhauser, R. (1999). Earnings Management to Exceed Thresholds. The Journal of Business, 72(1), 1-33. https://doi.org/10.1086/209601

Dezoort, F. T. (1998). An analysis of experience effects on audit committee members' oversight judgments. Accounting, Organizations and Society, 23(1), 1-21. https://doi.org/10.1016/S0361-3682(97)00029-9

Eagly, A. H., Karau, S. J., \& Makhijani, M. G. (1995). Gender and the effectiveness of leaders: A metaanalysis. Psychological Bulletin, 117(1), 125-145. https://doi.org/10.1037/00332909.117.1.125

Ekpulu, G. A., \& Omoye, A. S. (2018). Ownership Structure and Earnings Management: Evidence from Nigerian Listed Firms. 2(2), 57-74.

El Haddad, M. Y., \& Ez-Zarzari, Z. (2017). The Effect of the Presence of Audit Committees on Earnings Management in Morocco. European Scientific Journal, ESJ, 13(4), 225. https://doi.org/10.19044/esj.2017.v13n4p225

El Moslemany, R. E., \& Nathan, D. (2019). Ownership structure and Earnings Management: Evidence from Egypt. International Journal of Business \& Economic Development, 7(1), 18-32. https://doi.org/10.24052/IJBED/V07N01/ART-02

Fama, E. F. (1980). Agency Problems and the Theory of the Firm. Journal of Political Economy, 88(2), 288-307.

Fama, E. F., \& Jensen, M. C. (1983). Agency Problems and Residual Claims. The Journal of Law \& Economics, 26(2), 327-349.

Farooq, O. \& El Jai, H. (2012). Ownership structure and earnings management: evidence from the Casablanca stock exchange. International Research Journal of Finance and Economics, 84, 95-105.

Forker, J. J. (1992). Corporate Governance and Disclosure Quality. Accounting and Business Research, 22(86), 111-124. https://doi.org/10.1080/00014788.1992.9729426

Geraldes Alves, S. M. (2011). The effect of the board structure on earnings management: Evidence from Portugal. Journal of Financial Reporting and Accounting, 9(2), 141-160. https://doi.org/10.1108/19852511111173103

Ghosh, A., Marra, A., \& Moon, D. (2010). Corporate Boards, Audit Committees, and Earnings Management: Pre- and Post-SOX Evidence: corporate boards, audit committees, and earnings management. Journal of Business Finance \& Accounting, 37(9-10), 1145-1176. https://doi.org/10.1111/j.1468-5957.2010.02218.x

Gulzar, M. A., \& Zongjun, W. (2011). Corporate Governance Characteristics and Earnings 2021 | International Journal of Financial, Accounting, and Management/ Vol 3 No 3, 205-225 
Management: Empirical Evidence from Chinese Listed Firms. International Journal of Accounting and Financial Reporting, 1(1), 133-151. https://doi.org/10.5296/ijafr.v1i1.854

He, L., \& Yang, R. (2014). Does Industry Regulation Matter? New Evidence on Audit Committees and Earnings Management. Journal of Business Ethics, 123(4), 573-589. https://doi.org/10.1007/s10551-013-2011-9

Healy, P. M. (1985). The effect of bonus schemes on accounting decisions. Journal of Accounting and Economics, 7(1-3), 85-107. https://doi.org/10.1016/0165-4101(85)90029-1

Iraya, C., Mwangi, M., \& Muchoki, G. W. (2015). The effect of corporate governance practices on earnings management of companies listed at the Nairobi Securities Exchange. European Scientific Journal, ESJ, 11(1), 169- 178.

Jaggi, B., Leung, S., \& Gul, F. (2009). Family control, board independence and earnings management: Evidence based on Hong Kong firms. Journal of Accounting and Public Policy, 28(4), 281300. https://doi.org/10.1016/j.jaccpubpol.2009.06.002

Jensen, M. C. (1993). The Modern Industrial Revolution, Exit, and the Failure of Internal Control Systems. The Journal of Finance, 48(3), 831-880. https://doi.org/10.1111/j.15406261.1993.tb04022.x

Jensen, M. C., \& Meckling, W. H. (1976). Theory of the firm: Managerial behavior, agency costs, and ownership structure. Journal of Financial Economics, 3(4), 305-360. https://doi.org/10.1016/0304-405X(76)90026-X

John, K., \& Senbet, L. W. (1998). Corporate governance and board effectiveness. Journal of Banking \& Finance, 22(4), 371-403. https://doi.org/10.1016/S0378-4266(98)00005-3

Jouber, H., \& Fakhfakh, H. (2012). Earnings management and board oversight: An international comparison. Managerial Auditing Journal, 27(1), 66-86. https://doi.org/10.1108/02686901211186108

Jung, K., \& Kwon, S. Y. (2002). Ownership structure and earnings informativeness: Evidence from Korea. The International Journal of Accounting, 37(3), 301-325. https://doi.org/10.1016/S0020-7063(02)00173-5

Karamanou, I., \& Vafeas, N. (2005). The Association between Corporate Boards, Audit Committees, and Management Earnings Forecasts: An Empirical Analysis. Journal of Accounting Research, 43(3), 453-486. https://doi.org/10.1111/j.1475-679X.2005.00177.x

Katmon, N., \& Farooque, O. A. (2017). Exploring the Impact of Internal Corporate Governance on the Relation Between Disclosure Quality and Earnings Management in the U.K. Listed Companies. Journal of Business Ethics, 142(2), 345-367. https://doi.org/10.1007/s10551-015-2752-8

Kent, P., Routledge, J., \& Stewart, J. (2010). Innate and discretionary accruals quality and corporate governance. Accounting \& Finance, 50(1), 171-195. https://doi.org/10.1111/j.1467629X.2009.00321.X

Khazanchi, D. (1995). Unethical behavior in information systems: The gender factor. Journal of Business Ethics, 14(9), 741-749. https://doi.org/10.1007/BF00872327

Kjærland, F., Haugdal, A. T., Søndergaard, A., \& Vågslid, A. (2020). Corporate Governance and Earnings Management in a Nordic Perspective: Evidence from the Oslo Stock Exchange. Journal of Risk and Financial Management, 13(11), 256. https://doi.org/10.3390/jrfm13110256

Klein, A. (2002). Audit committee, board of director characteristics, and earnings management. Journal of Accounting and Economics, 33(3), 375-400. https://doi.org/10.1016/S0165-4101(02)00059$\underline{9}$

Kyaw, K., Olugbode, M., \& Petracci, B. (2015). Does gender diverse board mean less earnings management? Finance Research Letters, 14, 135-141. https://doi.org/10.1016/j.frl.2015.05.006

La Rosa, F., Bernini, F., \& Verona, R. (2020). Ownership structure and the cost of equity in the European context: The mediating effect of earnings management. Meditari Accountancy Research, 28(3), 485-514. https://doi.org/10.1108/MEDAR-12-2018-0421

Lary, A. M., \& Taylor, D. W. (2012). Governance characteristics and role effectiveness of audit committees. Managerial Auditing Journal, 27(4), 336-354. https://doi.org/10.1108/02686901211217969 
Law No. 17-95. Corporate Law relating to public limited companies. http://62.251.167.25/sites/default/files/Loi\%20relative\%20aux\%20SA\%20\%281\%29.pdf

Law No. 20-05. Corporate Law relating to public limited compagnies. https://oriental.eregulations.org/media/loi 20-05 modifiant la loi sur les sa.pdf

Law No. 20-19. Corporate Law relating to public limited companies. https://www.ammc.ma/sites/default/files/Loi\%20n\%C2\%B020-19.pdf

Lel, U. (2013). Can Institutional Investors Restrain Earnings Management Activities in Weak Investor Protection Countries? The Role of Foreign and Domestic Institutional Investors. SSRN Electronic Journal. https://doi.org/10.2139/ssrn.2223651

Lipton, M., \& Lorsch, J. W. (1992). A Modest Proposal for Improved Corporate Governance. The Business Lawyer, 48(1), 59-77.

Lubis, I., \& Adhariani, D. (2019). Corporate Governance, Earnings Management and Tax Avoidance: Indonesia Evidence. Proceedings of the 1st Sampoerna University-AFBE International Conference, SU-AFBE 2018, 6-7 December 2018, Jakarta Indonesia. https://doi.org/10.4108/eai.6-12-2018.2286317

Marra, A., Mazzola, P., \& Prencipe, A. (2011). Board Monitoring and Earnings Management Pre- and Post-IFRS. The International Journal of Accounting, 46(2), 205-230. https://doi.org/10.1016/j.intacc.2011.04.007

Matsumoto, D. A. (2002). Management's Incentives to Avoid Negative Earnings Surprises. The Accounting Review, 77(3), 483-514. https://doi.org/10.2308/accr.2002.77.3.483

McMullen, D. A., \& Raghunandan, K. (1996, August). Enhancing Audit Committee Effectiveness. Journal of Accountancy, 79-81.

Mnif, Y., \& Cherif, I. (2020). Female board directorship and earnings management. Pacific Accounting Review, ahead-of-print(ahead-of-print), Article ahead-of-print. https://doi.org/10.1108/PAR04-2020-0049

Molz, R. (1988). Managerial domination of boards of directors and financial performance. Journal of Business Research, 16(3), 235-249. https://doi.org/10.1016/0148-2963(88)90072-0

Obigbemi, I. F., Omolehinwa, E. O., Mukoro, D. O., Ben-Caleb, E., \& Olusanmi, O. A. (2016). Earnings Management and Board Structure: Evidence from Nigeria. SAGE Open, 6(3), 215824401666799. https://doi.org/10.1177/2158244016667992

Peasnell, K. V., Pope, P. F., \& Young, S. (2005). Board Monitoring and Earnings Management: Do Outside Directors Influence Abnormal Accruals? SSRN Electronic Journal. https://doi.org/10.2139/ssrn.249557

Powell, M., \& Ansic, D. (1997). Gender differences in risk behaviour in financial decision-making: An experimental analysis. Journal of Economic Psychology, 18(6), 605-628. https://doi.org/10.1016/S0167-4870(97)00026-3

Rajeevan, S., \& Ajward, R. (2019). Board characteristics and earnings management in Sri Lanka. Journal of Asian Business and Economic Studies, 27(1), 2-18. https://doi.org/10.1108/JABES03-2019-0027

Ramachandran, J., Ngete, Z. A., Subramanian, R., \& Sambasivan, M. (2015). Does corporate governance influence earnings management? Evidence from Singapore. The Journal of Developing Areas, 49(3), 263-274. https://doi.org/10.1353/jda.2015.0169

Rosenstein, S., \& Wyatt, J. G. (1990). Outside directors, board independence, and shareholder wealth. Journal of Financial Economics, 26(2), 175-191. https://doi.org/10.1016/0304$\underline{405 X(90) 90002-\mathrm{H}}$

S. Latif, A., \& Abdullah, F. (2015). The Effectiveness of Corporate Governance in Constraining Earnings Management in Pakistan. The Lahore Journal of Economics, 20(1), 135-155. https://doi.org/10.35536/lje.2015.v20.i1.a5

Sadjiarto, A., Monica, C. C., \& Budiarti, W. R. (2019). Ownership Structure and Earnings Management in Indonesian Listed Banks. Journal of Economics and Business, 2(1). https://doi.org/10.31014/aior.1992.02.02.85

Sae-Lim, P., \& Jermsittiparsert, K. (2019). Audit Committee and Earnings Quality. 6, 335-347.

Sáenz González, J., \& García-Meca, E. (2014). Does Corporate Governance Influence Earnings Management in Latin American Markets? Journal of Business Ethics, 121(3), 419-440. 
https://doi.org/10.1007/s10551-013-1700-8

Saleem Salem Alzoubi, E. (2016). Ownership structure and earnings management: Evidence from Jordan. International Journal of Accounting \& Information Management, 24(2), 135-161.

Saleh, N. M., Iskandar, T. M., \& Rahmat, M. M. (2005). Earnings Management and Board Characteristics: Evidence from Malaysia. Jurnal Pengurusan (UKM Journal of Management), 24(2005), 77-103.

Sbai, H., \& Meghouar, H. (2017). L'impact des mécanismes de gouvernance sur la performance des banques marocaines. Question(s) de management, $n^{\circ} 18(3), 173-187$.

Schipper, K. (1989). Commentary on Earnings Management. Accounting Horizons 3, 91-102.

Shah, K., \& Shah, A. (2014). The Impact of Corporate Governance and Ownership Structure on Earnings Management Practices: Evidence from Listed Companies in Pakistan. The Lahore Journal of Economics, 19(2), 27-70. https://doi.org/10.35536/lje.2014.v19.i2.a2

Sharma, V. D., \& Kuang, C. (2014). Voluntary Audit Committee Characteristics, Incentives, and Aggressive Earnings Management: Evidence from New Zealand: Voluntary Audit Committee Characteristics, Incentives, and Aggressive Earnings Management: Evidence from New Zealand. International Journal of Auditing, 18(1), 76-89. https://doi.org/10.1111/ijau.12013

Sierra García, L., Ruiz Barbadillo, E., \& Orta Pérez, M. (2012). Audit committee and internal audit and the quality of earnings: Empirical evidence from Spanish companies. Journal of Management \& Governance, 16(2), 305-331. https://doi.org/10.1007/s10997-010-9152-3

Stolowy, H., \& Breton, G. (2004). Accounts Manipulation: A Literature Review and Proposed Conceptual Framework. Review of Accounting and Finance, 3(1), 5-92. https://doi.org/10.1108/eb043395

Thiétart, R.-A., \& al. (2014). Méthodes de recherche en management (2ème édition). Dunod.

Thomsen, S., \& Pedersen, T. (2000). Ownership Structure and Economic Performance in the Largest European Companies. Strategic Management Journal, 21(6), 689-705.

Triki Damak, S. (2018). Gender diverse board and earnings management: Evidence from French listed companies. Sustainability Accounting, Management and Policy Journal, 9(3), 289-312. https://doi.org/10.1108/SAMPJ-08-2017-0088

Vicknair, D., Hickman, K., \& Carnes, K. C. (1993). A Note on Audit Committee Independence: Evidence from the NYSE on "Grey" Area Directors. Accounting Horizons: A Quarterly Publication of the American Accounting Association, 7(1), 305-332.

Villalonga, B., \& Amit, R. (2006). How do family ownership, control and management affect firm value? Journal of Financial Economics, 80(2), 385-417. https://doi.org/10.1016/j.jfineco.2004.12.005

Warfield, T. D., Wild, J. J., \& Wild, K. L. (1995). Managerial ownership, accounting choices, and informativeness of earnings. Journal of Accounting and Economics, 20(1), 61-91. https://doi.org/10.1016/0165-4101(94)00393-J

Watts, R. L., \& Zimmerman, J. L. (1986). Positive accounting theory. Prentice-Hall.

Waweru, N., \& Riro, G. K. (2013). Corporate Governance, Firm Characteristics and Earnings Management in an Emerging Economy. Journal of Applied Management Accounting Research, 11(1), 43-64.

Whittington, G. (1993). Corporate Governance and the Regulation of Financial Reporting. Accounting and Business Research, 23(sup1), 311-319. https://doi.org/10.1080/00014788.1993.9729899

Xie, B., Davidson, W. N., \& DaDalt, P. J. (2003). Earnings management and corporate governance: The role of the board and the audit committee. Journal of Corporate Finance, 9(3), 295-316. https://doi.org/10.1016/S0929-1199(02)00006-8 